\title{
Fiscal and Monetary Policy for Decent Employment in Nigeria
}

\author{
Philip Alege ${ }^{1}$, Jolaade A. Ayobami ${ }^{1} \&$ Jeremiah O. Ejemeyovwi $^{1}$ \\ ${ }^{1}$ Department of Economics \& Development Studies, Covenant University, Ota, Nigeria \\ Correspondence: Jeremiah O. Ejemeyovwi, Department of Economics \& Development Studies, Covenant University, \\ Ota, Nigeria.
}

Received: July 18, 2020

doi:10.5430/rwe.v12n1p351

Accepted: September 15, 2020

Online Published: February 20, 2021

URL: https://doi.org/10.5430/rwe.v12n1p351

\begin{abstract}
The level of unemployment in Nigeria has risen persistently, increasing the risk of the non-achievement of the SDG goal 8 - decent work and economic growth. Economists have documented that monetary and fiscal policies are effective tools for influencing economic variables such as the unemployment rate. In this study, we attempt to investigate and compare how these tools affect unemployment level in Nigeria. This study comes at an important time in Nigeria when the economy just exited a recession and is still experiencing low production and rising unemployment. This study investigates the nexus between macroeconomic policies and unemployment using the Autoregressive Distributed Lag (ARDL) estimation technique. The study finds that government capital expenditure helps to reduce unemployment in the long run only. On the other hand, the currency in circulation and the real GDP help to reduce unemployment rate in both the short and the long run. The study recommends a policy mix, which proposes that government expenditure be judiciously employed, and simultaneously, the Central Bank of Nigeria (CBN) should regulate the supply of money into the economy to not trigger inflation and unemployment.
\end{abstract}

Keywords: Autoregressive Distributed Lags (ARDL), decent work, economic growth, employment, fiscal policy, monetary policy, labour, SDG goal 8

JEL classification code: E24, E63

\section{Introduction}

The rising unemployment level in the global economy has received great attention from economists, world leaders, and the general public. With unemployment comes a negative economic implication such as the reduction in output, income, the number of taxable persons, and an increase in the dependency ratio. Such effects subsequently transmit into a decrease in government revenue and possibly expenditure as well. The rate of unemployment in Nigeria is on a persistent increase and has raised various concerns (Ubah, Bowale, Ejemeyovwi \& Okereke, 2021). A significant part of this concern is the risk of the non-achievement of the SDGs goal 8 -decent work and economic growth.

Nigeria is richly blessed with vast human and natural resources; however, despite the abundance of these resources, Africa's most populous country has been termed as one of the poorest countries in the globe and adjudged to rank among the countries with the highest unemployment rates in Sub-Saharan Africa (Anyadike, Emeh \& Ukah, 2012; Agbodike, Igbokwe-Ibeto \& Umeifekem, 2015; Ujumadu, 2016). Statistics show that Nigeria's unemployment rate rose to 14.2 percent (11.55 million) in the fourth quarter of 2016, up from 13.9 percent in the third quarter of 2016 and 13.3 percent in the second quarter of the same year (National Bureau of Statistics, 2017). This steadily rising unemployment rate in Nigeria poses a problem as it is postulated that the natural unemployment rate should be no higher than 5 percent. Thus, it becomes essential to empirically study the effects of fiscal and monetary policies on the Nigerian economy.

To drive decent employment in Nigeria, a need arises for the government to manage its spending in such a way that would help to create employment for the people, either through direct or indirect avenues. Through its numerous agencies and parastatals, the government could instantly create employment, which would be a direct avenue. This would, in turn, assist in reducing unemployment levels in the country. As an indirect avenue, the government could partner with some local and foreign organisations to employ its citizens through Public-Private Partnerships (PPPs). Such fiscal actions of decent work creation for the citizens would lead to higher income, higher consumption, and higher living standards, eventually transmitting into inclusive growth and development (Ejemeyovwi, Adiat \& Ekong, 2019; Ejemeyovwi, \& Osabuohien, 2020). Another indirect method of ensuring decent work for Nigerians is government expenditure, which has been established in literature to drive economic development. For example, 
government expenditure on public works and public projects (say, for instance, construction) would lead to the labor force's employment.

The Nigerian monetary authority has the mandate to promote full employment and price stability and manage monetary policy in Nigeria. Monetary policy is defined as "the specific actions taken by the central bank to regulate the value, supply and cost of money in the economy to achieve predetermined macroeconomic goals" (Central Bank of Nigeria, 2011). Thus, monetary policy involves utilizing variables and tools such as money supply and interest rate to influence economic activities and achieve their mandated goals.

The importance of monetary policy in influencing macroeconomic variables has evolved over the years. For instance, the Classical economists considered money as a "veil" and having no real effect on the economy, that is being neutral, and if, say, money supply increases with production being constant, they believe that nominal prices may rise, but the real value of the product would remain the same. Thus, in a classical world, money does not matter. However, over time, other groups of economists such as the Keynesians and the monetarists have debunked the claims by this school of thought that money was neutral in the economy. They found out that contrary to this view, money had effects on economic variables. Their argument was based on the premise that prices are sticky and not flexible. To them, with disequilibrium and unemployment, money is not neutral and had effects on real variables. Many economists have rejected the neutrality of money stance and agreed that the money supply variations affect the economy.

The rest of the study is arranged as follows: Section 2 deals with the literature review concerning the subject matter being studied. The theoretical framework and method of analysis are established in Section 3. Section 4 displays the findings and discussions of the results. The final Section articulates the conclusion and recommendations of the paper. It also presents some suggestions for further studies.

\section{Review of Empirical Literature}

Empirical studies analysed the varying effects that fiscal policy has on the unemployment level in different economies. Literature showed that an increase in private investment is efficient in unemployment reduction, and public investment permanent reductions seemed most related to the underlying longer-term rise in unemployment (Young \& Pedregal, 1999).

Unal (2015) analysed the effects of fiscal policy in the Netherlands. The study found that fiscal shocks had significant impacts on the rate of unemployment in the Netherlands. The results suggested that fiscal contraction led to a rise in unemployment, whereas a fiscal expansion did otherwise. The results also indicated that between social security taxes and total net taxes, the latter was a more effective tool for policy-makers in the Netherlands in terms of GDP and its determinants. Other studies have found that both government consumption and investment are useful in reducing unemployment. Government expenditure was found to crowd-in private consumption and investment (Matsumae \& Hasumi, 2016; Kuo \& Miyamoto, 2014; Rendahl, 2014; Leigh \& Neill, 2011; Monacelli, Perotti \& Trigari, 2010).

Bruckner and Pappa (2012) and Ding (2014) undertook studies on OECD countries. The studies found that the rate of unemployment significantly increased following increases in government expenditure. The studies further found that expansionary fiscal policy could substantially increase the unemployment rate for many OECD countries. However, the study's scope was limited only to OECD countries, and their result cannot be generalised to developing countries. The reason is that in many developed countries, resources have been maximally utilised, and government expenditure would crowd out private investment, which would lead to a contraction in output and employment. The same cannot be said for a developing country like Nigeria, where resources have not been thoroughly utilised. On the contrary, for developing countries such as Nigeria, Iran, and Colombia, government expenditure was found to reduce unemployment rates (Lozano \& Rodriguez, 2011; Arewa \& Nwakaha, 2013; Samira \& Khalil, 2015; Egbulonu \& Amadi, 2016). However, another study found the relationship between government expenditure and unemployment to be positive in Nigeria (Nwosa, 2014). Mahmood and Khalid (2013) investigated the relationship between fiscal policy and the rate of unemployment in Pakistan, a developing country, and obtained a similar result as Nwosa (2014).

Demonstrating how payroll tax bias affects unemployment level, Garcia and Sala (2008) showed that the unemployment rate is fuelled whenever the payroll taxes fall more on employees than firms. Similarly, Tagkalakis (2013), Kassab (2015), and Kaliontzakis (2015) discovered that the income tax rate negatively affected the employment level in Sweden and Greece, thus leading to higher unemployment. Another researcher, Aghazadeh, Akhoondzadeh, and Babazadeh (2014), carried out a study to discover the effects of corporate and labour income taxes on unemployment in Iran. They found a positive and significant effect of corporate and labor income taxes on 
Iran's unemployment rate. However, one shortcoming in this study was that its sample size was small (i.e., below 30) and may cause the results to be obtained not to be robust enough to make predictions and policy decisions. In a similar study, Alexius and Holmlund (2007), using Sweden as a case study, studied the effect of monetary policy on unemployment rate utilising a structural VAR model. The authors found that around one-third of the unemployment rate fluctuations was influenced by shocks to monetary policy and that the effects were relatively consistent. The study also found that contractionary monetary policy helped aggravate unemployment in Sweden. In a similar fashion but contrary note, Sunde (2015) carried out a study using a structural VAR methodology to analyse monetary policy's impact on unemployment in Namibia. The study showed that monetary policy was effective only in the short run but not in the long-run. The author thus recommended for further investigation to be carried out to explain the long-run unemployment found in Namibia.

Using a Bayesian model averaging procedure, Altavilla and Ciccarelli (2009) discovered that a monetary policy shock is less impactful than other structural shocks in explaining unemployment in the country but had a constant recessionary effect in both the euro area and the US. In 2011, Engler analysed monetary policy's influence on unemployment in open economies. He found that the unemployment rate was reduced following an expansionary monetary policy shock, which subsequently led to a much more beneficial effect on citizens' welfare. In a study to show the impact of fiscal and monetary policies in Nigeria, Attamah, Anthony, and Ukpere (2015) found an increase in government expenditure raised unemployment while government revenue did otherwise. It was also noted that expansionary monetary policy was found to reduce unemployment in the country.

In all, there has been extensive research done on unemployment by various authors considering the various policies that could be used to reduce it. In the studies considered, the authors studied the effects of either fiscal policy or monetary policy, and not both, on unemployment. Our study deviates from the existing literature in that we consider the effect of both fiscal and monetary policies on unemployment in the same model. In addition to this, we disaggregate government expenditure into its recurrent and capital components and study their effects on unemployment. Our decision to do so is informed by studies that show that the two components have varying impacts on the economy (Butkiewicz \& Yanikkaya, 2011; Attari \& Javed, 2013; Ogundipe \& Oluwatobi, 2013; Ranasinghe \& Ichihashi, 2014; Morozumi \& Veiga, 2016). These studies suggest that one component has more effect than the other in stimulating the economy. Therefore, this study attempts to study the effect of government expenditure on the unemployment rate in Nigeria. In light of these, our analysis thus offers its uniqueness and adds to the existing literature.

\section{Methodology}

This study is anchored on the Keynesian theory of employment, which relates to the principle of effective demand. John Maynard Keynes opined that the level of employment in the short run depends on the effective demand. Effective demand refers to the demand for goods and services, backed up by the ability and willingness to pay. According to Keynes, a significant increase in aggregate demand would influence employment and vice-versa (Keynes, 2018). A decline in total effective demand would lead to unemployment.

From theory, Keynesian unemployment is the deviation of unemployment from its natural rate. The natural rate of unemployment is the unemployment rate that exists when the labour market is at equilibrium. It usually arises due to structural and frictional unemployment. The Keynesian unemployment fluctuates around this natural rate of unemployment. Keynesian unemployment is caused by downturns in the economy that are part of the business cycle, which are the natural fluctuations in the economy (Amu, Osabuohien, Ejemeyovwi, \& Alege, 2021). To reduce the Keynesian unemployment, there must be a rise in the consumption of newly-produced goods and services via aggregate demand. An increase in the demand for such newly produced goods and services would encourage producers to step up production, which would, in turn, create a derived demand for labour services. An increase in the demand for labour would subsequently lead to a rise in unemployment and a decline in unemployment. Thus, an increase in the aggregate demand tends to reduce unemployment (Keynes, 2018).

\subsection{Model Specification}

This study investigates the existence of a long-run relationship among the unemployment rate, fiscal and monetary policies, and economic growth in Nigeria. The model adopted in this study is expressed in both its implicit and explicit forms and is shown in equations (1) and (2) respectively as follows:

$$
U N E R_{t}=f\left(G C E X_{t}, G R E X_{t}, C U I C_{t}, G D P C_{t}\right)
$$

Where $t$ denotes the time. The paper assumed non-linearity in the relationship between the dependent variable and the explanatory variables such that equation (1) is rewritten as: 


$$
U N E R_{t}=\alpha_{0} G C E X^{\alpha_{1}} G R E X^{\alpha_{2}} \operatorname{CUIC}^{\alpha_{3}} G D P C^{\alpha_{4}} e^{\mu_{t}}
$$

Where $\mu_{t}$ denotes the error term. $\alpha_{i}$ (for $i=1,2,3,4$ ) represent the coefficients and $\alpha_{0}$ is the constant term. Log-linearization of equation (2) yields the following expression:

$$
\text { LNUNER }=\alpha_{0}+\alpha_{1} L N G C E X+\alpha_{2} L N G R E X+\alpha_{3} L N C U I C+\alpha_{4} L N G D P C+\mu_{t}
$$

Where UNER, GCEX, GREX, CUIC, and RGDP represent the unemployment rate, government capital expenditure, recurrent government expenditure, currency in circulation, and the real Gross Domestic Product, respectively. LN represents the natural logarithm. The inclusion of these particular explanatory variables is based on their relevance in combating unemployment, as shown in the existing theoretical and empirical literature.

\subsection{Technique of Estimation}

A preliminary examination of the model variables' time-series properties indicated a mixture of $\mathrm{I}(0)$ and $\mathrm{I}(1)$ series. Consequently, the Autoregressive Distributed Lag (ARDL) Model becomes the appropriate estimation technique in this regard. Pesaran, Shin, and Smith (2001) developed the ARDL Model as an econometric tool used to determine cointegration when a mixture of $\mathrm{I}(0)$ and $\mathrm{I}(1)$ variables exists after running the stationarity test. The caveat for using the ARDL model is that it cannot be used in the presence of I(2) variables. The ARDL equation for this study is specified as follows:

$$
\begin{aligned}
& \triangle L N U N E R_{t}=\beta_{0}+\sum_{i=1}^{p} \beta_{1} \Delta L N U N E R_{t-i}+\sum_{i=0}^{p} \beta_{2} \Delta L N G C E X_{t-i}+\sum_{i=0}^{p} \beta_{3} \Delta L N G R E X_{t-i}+\sum_{i=0}^{p} \beta_{4} \Delta L N C U I C_{t-i}+ \\
& \sum_{i=0}^{p} \beta_{5} \Delta L N G D P C_{t-i}+\varphi_{1} L N U N E R_{t-1}+\varphi_{2} L_{N} G C E X_{t-1}+\varphi_{3} L_{N} \text { GREX } X_{t-1}+\varphi_{4} L_{N C U I C} C_{t-1}+\varphi_{5} L_{N} G D P C_{t-1}+\mu_{t}
\end{aligned}
$$

In equation (4) above, $\beta_{1}, \beta_{2}, \beta_{3}, \beta_{4}$ and $\beta_{5}$ represent the short-run coefficients (elasticities) of the ARDL model while $\varphi_{1}, \varphi_{2}, \varphi_{3}, \varphi_{4}$ and $\varphi_{5}$ represent the long-run coefficients(elasticities) of the ARDL model. $\beta_{0}$ represents the constant term and $\mu_{t}$ signifies the disturbance term or the white noise.

Once cointegration has been established amongst the variables of interest, the long-run relationship is estimated by using the conditional ARDL model specified as follows:

$$
\text { LNUNER }_{t}=\beta_{0}+\varphi_{1} \text { LNUNER }_{t-1}+\varphi_{2} L_{N} \text { GCEX }_{t-1}+\varphi_{3} L_{N} \text { GREX } X_{t-1}+\varphi_{4} L_{N C U I C}+1+\varphi_{5} L N G D P C_{t-1}+\mu_{t}
$$

Following this, the short-run dynamic relationship of the model is estimated by using the Error Correction Model $(\mathrm{ECM})$, which is specified as follows:

$$
\begin{aligned}
\Delta L N U N E R_{t}= & \beta_{0}+\sum_{i=1}^{p} \beta_{1} \Delta L N U N E R_{t-i}+\sum_{i=0}^{p} \beta_{2} \Delta L N G C E X_{t-i}+\sum_{i=0}^{p} \beta_{3} \Delta L N G R E X_{t-i}+ \\
& \sum_{i=0}^{p} \beta_{4} \Delta L N C U I C_{t-i}+\sum_{i=0}^{p} \beta_{5} \Delta L N G D P C_{t-i}+\omega E C T_{t-1}+\mu_{t}
\end{aligned}
$$

$E C T_{t-1}$ refers to the one-period lagged Error Correction Term. $\omega$ is the coefficient of the error correction term, and it refers to the speed of adjustment back to equilibrium. $\Delta$ is the first difference operator, while $p$ refers to the lag length of the ARDL model and $t$ refers to the time.

\subsection{Data Sources and Measurements}

This study uses annual time series spanning thirty-two (32) years ranging from 1985 to 2016. The choice of years was solely due to the (un)availability of data. The variables of interest in this study include the unemployment rate (UNER), fiscal policy (which is proxied by government capital expenditure (GCEX) and recurrent government expenditure (GREX)), monetary policy (which is proxied by currency in circulation (CUIC)) and the real Gross Domestic Product (RGDP). Table 1 below presents the data, their measurements, and sources.

Table 1. Data description, measurement and source

\begin{tabular}{llll}
\hline Variable & Description & Measurement & Source \\
\hline UNER & Unemployment Rate & Percentage (\%) & National Bureau of Statistics, 2017 \\
\hline GCEX & Government Capital Expenditure & Billion Naira (®) & CBN Statistical Bulletin, 2016 \\
\hline GREX & Government Recurrent Expenditure & Billion Naira (N) & CBN Statistical Bulletin, 2016 \\
\hline CUIC & Currency in Circulation & Billion Naira (N) & CBN Statistical Bulletin, 2016 \\
\hline RGDP & Real Gross Domestic Product & Billion Naira (®) & CBN Statistical bulletin, 2016 \\
\hline
\end{tabular}

Source: Authors' Compilation 


\section{Results}

\subsection{Stationarity Test}

In dealing with time-series data, it is necessary to check for unit root to determine whether the series is stationary or not. This is because time series are usually non-stationary, and the use of such data in econometric analysis could lead to the generation of spurious results. For this reason, the unit root test, which is used to test for the stationarity of the time series, is used. This study proceeds by using two different popular unit root tests - the Augmented Dickey-Fuller (ADF) unit root test and the Phillips-Peron unit root test - to determine whether the following log-linearized time series is stationary or not: LNUNER, LNGCEX, LNGREX, LNCUIC, and LNRGDP. The result of the unit root test is presented in Table 2. As seen from Table 2, some of the variables of importance in this study are stationary after first differencing while the others are stationary at level. With stationarity of different orders established, the ARDL Bounds test is carried out to achieve this study's objective.

Table 2. ADF and PP Unit Root Tests

\begin{tabular}{llllll}
\hline & ADF TEST & & PP TEST & \\
\hline Variables & Level & First Difference & Level & First Difference & Order \\
\hline LNUNER & -0.227152 & $-3.989144 *$ & -0.288259 & $-4.709462 *$ & I(1) \\
\hline LNGCEX & -2.394081 & $-5.877959 *$ & -2.609685 & $-5.894500 *$ & I(1) \\
\hline LNGREX & $-3.075225 *$ & - & $-5.308721 *$ & - & I(0) \\
\hline LNCUIC & $-4.487834 *$ & - & $-2.905330 * * *$ & - & I(0) \\
\hline LNRGDP & -0.330420 & $-2.795601 * * *$ & 0.561215 & $-2.777957 * *$ & I(1)
\end{tabular}

Where $*, * *$ and $* * *$ indicate the $1 \%, 5 \%$ and $10 \%$ levels of significance for the Test Critical Values.

Source: Authors' Computation via EViews 10

\subsection{The ARDL Bounds Testing Approach to Cointegration}

Based on both the ADF and PP unit root tests that were conducted, it is discovered that three (LNUNER, LNGCEX, and LNRGDP) of the five variables are stationary after first differencing. At the same time, the other two (LNGREX and LNCUIC) are stationary at level. For this reason, the ARDL Bounds test is used to achieve the objective of this study: to investigate the long-run relationship amongst unemployment, fiscal policy and monetary policy, and economic growth in Nigeria.

\subsection{Optimal Lag Selection}

Before proceeding to the ARDL Bounds testing, it is essential to determine and select the optimal lag length $(p)$ that best fits the model. This selection is made through the use of the Vector Autoregressive (VAR) model. The optimal lag length is selected by choosing the optimum of the various lag selection criteria. The different lag selection criteria include the Likelihood Ratio (LR), the Final Prediction Error (FPE), the Akaike Information Criterion (AIC), the Schwarz Information Criterion (SC), and the Hannan-Quinn Criterion (HQC). The results of the optimal lag selection for the different criteria are presented in Table 3. From the Table, all of the various criteria select Lag 1 as the optimal lag order. Thus, for the ARDL model in this study, the lag order to be adopted is 1 . That is $p=1$.

Table 3. VAR Lag order selection criteria

\begin{tabular}{lllllll}
\hline Lag & LogL & LR & FPE & AIC & SC & HQ \\
\hline $\mathbf{0}$ & -65.39652 & NA & $7.51 \mathrm{e}-05$ & 4.693102 & 4.926634 & 4.767811 \\
\hline $\mathbf{1}$ & 116.7306 & $291.4035^{*}$ & $2.18 \mathrm{e}-09^{*}$ & $-5.782043^{*}$ & $-4.380846^{*}$ & $-5.333788^{*}$ \\
\hline $\mathbf{2}$ & 137.336 & 26.09713 & $3.40 \mathrm{e}-09$ & -5.488910 & -2.920048 & -4.667109 \\
\hline
\end{tabular}

Where * denotes the lag order selected by the criterion.

Source: Authors' Computation via EViews 10 
Next, this study proceeds to carry out the ARDL Bounds test.

\subsection{ARDL Bounds Test}

Having established stationarity of the variables at orders I $(0)$ and I(1), the study proceeds to determine the existence of cointegration amongst the variables of interest. This is achieved by using the ARDL Bounds Test. Pesaran et al. (2001) suggested using the F-test to examine the lagged variables' joint significance. The null hypothesis $\left(H_{0}\right)$ of no cointegration amongst the variables is established based on the Wald test by imposing restrictions on the estimated long-run coefficients of the lagged variables equal to zero (Karimi \& Rodgar, 2018). The hypothesis is shown as:

$$
H_{0}=\varphi_{1}=\varphi_{2}=\varphi_{3}=\varphi_{4}=\varphi_{5}=0
$$

The corresponding alternate hypothesis is shown as:

$$
H_{1} \neq \varphi_{1} \neq \varphi_{2} \neq \varphi_{3} \neq \varphi_{4} \neq \varphi_{5} \neq 0
$$

Then, the computed F-statistic is compared to the critical value obtained from the upper and lower Bounds. The decision rule is explained as follows: If the F statistic is lower than the lower bound, I (0), then the null hypothesis of no cointegration amongst the variables is accepted. If the F statistic is greater than the upper bound, I (1), then the null hypothesis of no cointegration amongst the variables is rejected. If the F statistic lies between the lower bound and the upper Bound, then the cointegration is inconclusive.

With this understanding, the result of the ARDL test is presented in Table 4 below. From the Table, the F-Statistic value is greater than the critical value of both the lower and the upper bounds at all the levels of significance. As a result, the null hypothesis of no cointegration is rejected. Thus, cointegration exists among LNUNER, LNGCEX, LNGREX, LNCUIC, and LNRGDP for the period under consideration (1985-2016). K denotes the number of parameters.

Table 4. ARDL Bounds Test

\begin{tabular}{lll}
\hline TEST STATISTIC & VALUE & K \\
\hline F-Statistic & 7.34 & 4 \\
\hline CRITICAL VALUE BOUNDS & & \\
\hline SIGNIFICANCE & I(0) Bound & I(1) Bound \\
\hline $\mathbf{1 0 \%}$ & 2.2 & 3.09 \\
\hline $\mathbf{5 \%}$ & 2.56 & 3.49 \\
\hline $\mathbf{2 . 5 \%}$ & 2.88 & 3.87 \\
\hline $\mathbf{1 \%}$ & 3.29 & 4.37 \\
\hline
\end{tabular}

Source: Authors' Computation via EViews 10

After cointegration is established, this study proceeds to determine the coefficients of the long-run relationship. Before that, it is vital to determine the selection criteria of the ARDL model.

\subsection{ARDL Model Selection Criteria}

The result of the ARDL Model selection criteria is shown in Figure 1. The Figure shows the ARDL model selection criteria based on the Akaike Information Criteria (AIC). The top 20 models are shown. The decision rule is to select the ARDL model that is the minimum. From Figure 1 below, it is seen that the ARDL $(1,2,3,3,2)$ model is the minimum. Thus, it is this model that is adopted in this study. 


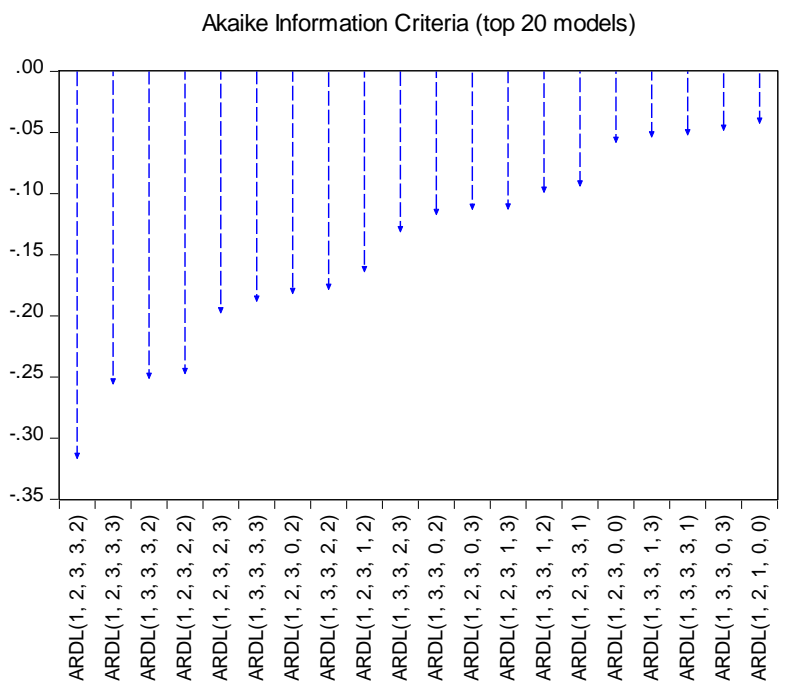

Figure 1. ARDL model selection criteria

Source: Authors' Computation via EViews 10.

Having determined the ARDL model criteria, this study proceeds to determine the coefficients of the long-run relationship.

\subsection{The Long Run Relationship}

The coefficients of the long-run relationship are presented in Table 5. They are interpreted as elasticities. The result shows that all the explanatory variables are elastic. It is seen that government capital expenditure bears a positive relationship with the unemployment rate in Nigeria. Specifically, a 1 percent increase in government capital expenditure will lead to a 1.90 percent increase in the unemployment rate. Likewise, recurrent government expenditure bears a positive relationship with the unemployment rate in Nigeria. Specifically, a 1 percent increase in government recurrent expenditure will lead to a 6.55 percent increase in the unemployment rate. On the other hand, the currency in circulation has a negative relationship with Nigeria's unemployment rate. In specific terms, a 1 percent increase in the currency in circulation will lead to a 7.16 percent decrease in the unemployment rate. Similarly, the real GDP has a negative relationship with the unemployment rate. Specifically, a 1 percent increase in the real GDP will lead to a 4.08 percent decrease in the unemployment rate. $1.90,6.55,-7.16$ and -4.08 are $\varphi_{2}, \varphi_{3}, \varphi_{4}$ and $\varphi_{5}$ respectively which are the long-run coefficients in equation (5). All the variables are statistically significant.

Table 5. Long run coefficients (Dependent variable: LNUNER)

\begin{tabular}{lcccl}
\hline VARIABLE & COEFFICIENT & STD. ERROR & T-STATISTIC & PROB. \\
\hline LNGCEX & 1.90 & 0.62 & 3.04 & 0.00 \\
\hline LNGREX & 6.55 & 1.94 & 3.37 & 0.00 \\
\hline LNCUIC & -7.16 & 2.12 & -3.37 & 0.00 \\
\hline LNRGDP & -4.08 & 1.51 & -2.69 & 0.01 \\
\hline C & 36.53 & 13.44 & 2.71 & 0.01 \\
\hline
\end{tabular}

Source: Authors' Computation via E Views 10

The long-run equation is thus expressed as follows:

Cointeq $=$ LNUNER $-(1.90 *$ LNGCEX $+6.55 *$ LNGREX $-7.16 *$ LNCUIC $-4.08 *$ LNRGDP + 36.53 $)$ 


\subsection{The Short Run Relationship}

Having established a long-run relationship amongst the variables, it is necessary to check for the existence of a short-run relationship amongst the variables of interest. The short-run coefficients are presented in Table 6 . The Table shows that the coefficient of the lagged error term (which is $\omega$ in equation (6)) fulfills the criterion of being significant and $0<E C T_{t-1} \leq 1$. This finding implies that about 41.67 percent of disequilibrium in the economy is corrected. As a result of this, there is the existence of a short-run relationship amongst the variables being considered. In addition, it is seen that in the short run, the two components of government expenditure possess different effects on unemployment.

Table 6. Short run coefficients (Dependent variable: LNUNER)

\begin{tabular}{lllll}
\hline VARIABLE & COEFFICIENT & STD. ERROR & T-STATISTIC & PROB. \\
\hline D(LNGCEX) & -0.0214 & 0.1801 & -0.1190 & 0.9071 \\
\hline D(LNGREX) & 0.6816 & 0.2021 & 3.3733 & 0.0050 \\
\hline D(LNCUIC) & -2.4921 & 0.6086 & -4.0942 & 0.0013 \\
\hline D(LNRGDP) & -4.0664 & 2.5817 & -1.5751 & 0.1392 \\
\hline ECM(-1) & -0.4166 & 0.0533 & -7.8136 & 0.0000 \\
\hline
\end{tabular}

Note: $\mathrm{D}$ in Table 6 above represents $\Delta$ in equation (6), which is the first difference operator

Source: Authors' Computation Via E Views 10

\subsection{Robustness Checks}

To ensure that the results obtained from the estimated ARDL model are free from the various problems associated with long-run estimations, some robustness checks, including the model diagnostic and stability tests, are carried out. The results are presented below.

\subsection{Model Diagnostic Tests}

In order to utilise the results from the ARDL model, it is necessary to carry out some model diagnostic tests. To this end, the following tests are used: The Jarque-Bera Normality Test, the Breusch-Godfrey Serial Correlation LM Test, the Breusch-Pagan-Godfrey Heteroskedasticity Test, and the Ramsey RESET Test. The results of these diagnostic tests are presented in Table 7 below. The Jarque-Bera Normality test shows that the residual (error term) of the ARDL model is normally distributed since the probability is greater than 0.05 , thus accepting the null hypothesis of normal distribution. The Breusch-Godfrey Serial Correlation LM Test reveals the absence of serial correlation as its probability is greater than 0.05 , thus accepting the null hypothesis of no serial correlation. In addition, the Breusch-Pagan-Godfrey Heteroskedasticity Test reveals that the model shows no evidence of heteroskedasticity since the probability is greater than 0.05 , thus accepting the null hypothesis of no heteroskedasticity. Thus, the model is homoskedastic. The Ramsey RESET Test results present no evidence of functional form misspecification in the ARDL model as its probability is greater than 0.05 , thus accepting the null hypothesis of no functional form misspecification. In sum, it can be safely concluded that the ARDL $(1,2,3,3,2)$ model is efficient, and its results can be relied upon as the model passes all the diagnostic tests carried out.

Table 7. Model Diagnostic Tests

\begin{tabular}{|c|c|c|c|}
\hline \multicolumn{4}{|c|}{ JARQUE-BERRA NORMALITY TEST } \\
\hline Jarque-Bera & 2.884475 & Probability & 0.236398 \\
\hline \multicolumn{4}{|c|}{ BREUSCH-GODFREY SERIAL CORRELATION LM TEST } \\
\hline F-Statistic & 1.499690 & Prob. F(1,12) & 0.2442 \\
\hline Obs*R-squared & 3.221630 & Prob. Chi-Square(1) & 0.0727 \\
\hline \multicolumn{4}{|c|}{ BREUSCH-PAGAN-GODFREY HETEROSKEDASTICITY TEST } \\
\hline F-statistic & 0.936026 & Prob. F(15, 13) & 0.5534 \\
\hline
\end{tabular}




\begin{tabular}{llll}
\hline Obs*R-squared & 15.05790 & Prob. Chi-Square(15) & 0.4473 \\
\hline Scaled explained SS & 3.581638 & Prob. Chi-Square(15) & 0.9988 \\
\hline RAMSEY RESET TEST & & & \\
\hline & Value & df & Probability \\
\hline F-statistic & 1.620075 & $(1,12)$ & 0.2272
\end{tabular}

Source: Authors' Computation via E Views 10

\subsection{Stability Tests}

Next, the stability of the selected ARDL model is determined. To this end, the CUSUM (Cumulative Sum) Test and the CUSUMSQ (Cumulative Sum of Squares) Test are both used. While the CUSUM Test is used for examining systematic changes in the estimated model coefficients, the CUSUMSQ is used to review changes that are sudden and accidental in the stability of the estimated model coefficients (Mohseni \& Jouzaryan, 2016). The decision rule is that when the plots of the model lie within the critical boundaries at 5 percent significance level, the estimated long-run and short-run parameters of the ARDL model are constant and stable. The results from these tests are provided below in Figure 2 and Figure 3, respectively. The figures show that the estimated coefficients of the long and short-run parameters in the unemployment rate equation for Nigeria are stable and could be used for economic inferences.

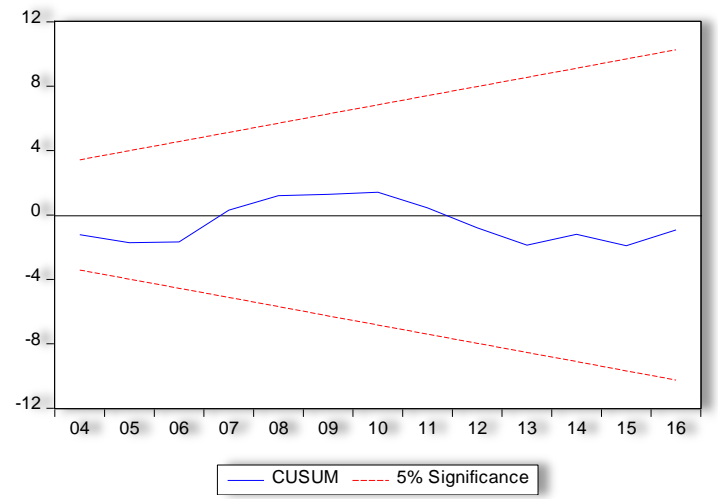

Figure 2. The plot of CUSUM (Cumulative Sum) test

Source: Authors' Computation via EViews 10

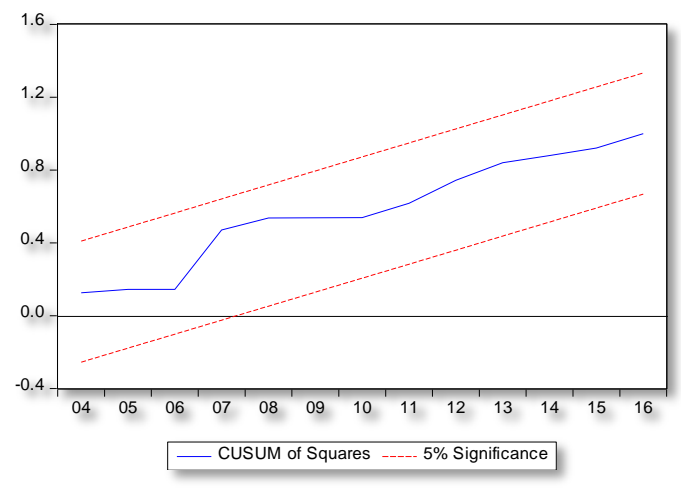

Figure 3. The plot of CUSUMSQ (Cumulative Sum of Squares) test Source: Authors' Computation via EViews 10 


\subsection{Granger Causality Test}

With the establishment of both long-run and short-run relationships amongst the unemployment rate, the two components of government expenditure, currency in circulation, and economic growth, this study proceeds to investigate the direction of causality of these variables. The decision rule for the Granger Causality Test is that when the probability value is less than 0.05 , the null hypothesis of no Granger Causality is rejected, while it is accepted when the probability value is greater than 0.05 . The result of the Granger Causality Test is presented in Table 8 below. The Granger Causality Test results reveal the presence of unidirectional causality flowing from government capital expenditure, recurrent government expenditure, currency in circulation, and economic growth to the unemployment rate.

Table 8. Pairwise Granger Causality Test

\begin{tabular}{lllll}
\hline Null hypothesis & F-Statistic & Prob. & Decision & Causality \\
\hline LNGCEX does not Granger Cause LNUNER & 8.93587 & 0.0058 & Reject & Unidirectional \\
LNUNER does not Granger Cause LNGCEX & 2.34608 & 0.1368 & Accept & \\
\hline LNGREX does not Granger Cause LNUNER & 4.78315 & 0.0373 & Reject & Unidirectional \\
LNUNER does not Granger Cause LNGREX & 0.00350 & 0.9532 & Accept & \\
\hline LNCUIC does not Granger Cause LNUNER & 5.84899 & 0.0223 & Reject & Unidirectional \\
LNUNER does not Granger Cause LNCUIC & 1.81721 & 0.1885 & Accept & \\
\hline LNRGDP does not Granger Cause LNUNER & 3.16127 & 0.0223 & Reject & Unidirectional \\
LNUNER does not Granger Cause LNRGDP & 9.15489 & 0.1885 & Accept & \\
\hline
\end{tabular}

Source: Authors' Computation via E Views 10

From the results obtained by the study, it is seen that fiscal policy aggravates the unemployment menace in Nigeria. The reasons behind this may be as a result of wasteful and ineffective government. Perhaps, projects being embarked on by the government destroy more jobs than it creates. Another reason may be traced to the unsustainability of employment generated through government projects (Ejemeyovwi, \& Osabuohien, 2020). It is the norm in Nigeria that, with every new administration in power, personalised projects come up such that the existing ones initiated by past administrations are left to suffer. This may be seen as a lack of continuity in government projects. It is thus recommended that government should ensure continuance of its projects, even those of past administrations. Also, as much as possible, where feasible, jobs should not be outsourced to foreigners (Matthew et al., 2018).

The study finds that monetary policy could be the only macroeconomic tool that reduces unemployment in Nigeria. This may work through the mechanism of increased velocity of money. With more currency in circulation, people consume more and money changes hands quickly, production is increased and employment is created. The overall effect of this is the reduction of unemployment. The real GDP is also seen to reduce unemployment in Nigeria. This implies that more jobs would be created with better economic performance and income distribution, and more people would not be left unemployed (Ejemeyovwi, Adiat \& Ekong, 2019). One reason for this may be that more people can increase their consumption and demand with an improved economy. This could encourage more people to go into businesses and create more jobs (Ejemeyovwi, Osabuohien, \& Osabuohien, 2018). This, in turn, raises production and more employment. Overall, unemployment is reduced, and sustainable development (SDG) goal 8 (decent work and economic growth) as of 2030 is relatively assured.

Having established the role of fiscal and monetary policy empirically and discussed the effect and linkage to unemployment, and SDG goal 8, it is also important to emphasise that solving the issue of unemployment could also contribute significantly to the reduction of poverty as well as translate into good health, wellbeing and quality education, which are clearly SDG goals 1, 3 and 4 respectively. A better standard of living is expected through the engagement of the economy's labour force, thereby increasing the ability of each labour participant to happily meet the person's needs in terms of good healthcare attainment, which include regular check-ups for the person and the person's family; afford good quality education and overall increase the level of happiness of the labour force participants in the country (Ejemeyovwi, Osabuohien, Johnson \& Bowale, 2019). 


\section{Conclusion and Recommendations}

This study was conducted to empirically investigate and suggest reliable policy instrumentation that will make the attainment of the sustainable development goal 8 - decent work and economic growth - feasible for Nigeria. With this view, this study examines the relationship between fiscal policy, monetary policy and unemployment in Nigeria within the period 1985 - 2016. One significant finding of this study is that while both government capital and recurrent expenditures bear positive relationships with the rate of unemployment in the long run, they bear different relationships in the short run. Specifically, government capital expenditure helps to reduce unemployment in the long run only. On the other hand, the currency in circulation and the real GDP help to reduce unemployment rate in both the short and the long run. This study recommends that government should take caution and carefully evaluate both its capital and recurrent expenditure so as not to aggravate the unemployment problem in Nigeria. In addition, caution must be taken by the monetary authority in order to ensure that there is no explosion of currency in circulation as the resulting effect may be a high inflation rate which could end up increasing unemployment in the long run. This will be a counter-effect of monetary policy.

\section{Acknowledgment}

The authors appreciate Covenant University Centre for Research Innovation and Disccovery (CUCRID) for the publication support and the Center for Economic Policy and Development Research (CEPDeR), Covenant University for the equipment support, which aided the production of the manuscript.

\section{References}

Agbodike, C. F., Igbokwe-Ibeto, C. J., \& Umeifekem, U. (2015). Youth unemployment and labour productivity in Nigeria in Nigeria: The Nexus. Journal of Research and Development, 2(8), 14-28. https://doi.org/10.12816/0017360

Aghazadeh, E., Akhoondzadeh, T., \& Babazadeh, M. (2014). Unemployment and taxes in Iran: An empirical study of the effects of corporate and labour income tax on unemployment. Indian Journal of Fundamental and Applied Life Sciences, 4, 355-364.

Alexius, A., \& Holmlund, B. (2007). Monetary policy and swedish unemployment fluctuations. IZA Discussion Paper No. 2933. https://doi.org/10.2139/ssrn.1716637

Altavilla, C., \& Ciccarelli, M. (2009). The effects of monetary policy on unemployment dynamics under model uncertainty: Evidence from the US and the Euro area. European Central Bank Working Paper Series No. 1089. https://doi.org/10.1111/j.1538-4616.2009.00256.x

Amu, B., Osabuohien, E. S., Alege, P. O., \& Ejemeyovwi, J. O. (2021). Impact of Real Shocks on Business Cycles in selected Sub-Saharan African Countries. Cogent Business \& Management, 8(1). https://doi.org/10.1080/23311975.2021.1875548

Anyadike, N., Emeh, I. E., \& Ukah, F. O. (2012). Entrepreneurship development and employment generation in Nigeria: Problems and prospects. Universal Journal of Education and General Studies, 1(4), 88-102.

Arewa, A., \& Nwakahma, P. C. (2013). Macroeconomic variables and the dynamic effect of public expenditure: long-term trend analysis in Nigeria. Journal of Knowledge Management, Economics and Information Technology, III(6), 1-32. Retrieved from www.scientificpapers.org

Attamah, N., Anthony, I., \& Ukpere, W. I. (2015). The impact of fiscal and monetary policies on unemployment problem in Nigeria (managerial economic perspective). Risk Governance \& Control: Financial Markets \& Institutions, 5(2), 101-109. https://doi.org/10.22495/rgcv5i2c1art4

Attari, M. I., \& Javed, A. Y. (2013). Inflation, economic growth and government expenditure of Pakistan: 1980-2010. Procedia Economics and Finance, 5, 58-67. https://doi.org/10.1016/S2212-5671(13)00010-5

Bruckner, M., \& Pappa, E. (2012). Fiscal expansions, unemployment and labour force participation: Theory and evidence. International Economic Review, 53(4), 1205-1228. https://doi.org/10.1111/j.1468-2354.2012.00717.x

Butkiewicz, J. L., \& Yanikkaya, H. (2011). Institutions and the impact of government spending on growth. Journal of Applied Economics, 14(2), 319-341. https://doi.org/10.1016/S1514-0326(11)60017-2

Central Bank of Nigeria. (2011). Central bank of nigeria monetary policy framework. Understanding Monetary Policy Series No. 3. 
Ding, H. (2014). Unemployment and welfare states: what do the data tell us?. Journal of Social Sciences for Policy Implication, 2(2), 197-226.

Egbulonu, K. G., \& Amadi, K. W. (2016). Effect of fiscal policy on unemployment in the Nigerian economy. International Journal of Innovative Finance and Economics Research, 4(3), 1-7.

Ejemeyovwi, J. O., \& Osabuohien, E. S. (2020). Investigating mobile technology adoption and inclusive growth in West Africa. Contemporary Social Science, 15(1), 48-61. https://doi.org/10.1080/21582041.2018.1503320

Ejemeyovwi, J. O., Osabuohien, E. S., \& Osabuohien, R. (2018). Investment in technology and human capital development in ECOWAS. International Journal Economics and Business Research, 15(4), 463-474. https://doi.org/10.1504/IJEBR.2018.092151

Ejemeyovwi, J. O., Osabuohien, E. S., Johnson, O. D., \& Bowale, K. E. (2019). Internet usage and inclusive growth in West Africa. Journal of Economic Structures, 8(1), 15. https://doi.org/10.1186/s40008-019-0146-2

Ejemeyovwi, J., Adiat, Q., \& Ekong, E. (2019). Energy Usage, Internet Usage and Human Development in Selected Western African Countries. International Journal of Energy Economics and Policy, 9(5), 1-6. https://doi.org/10.32479/ijeep.7611

Engler, P. (2011). Monetary policy and unemployment in open economies. NCER Working Paper No. 77. https://doi.org/10.2139/ssrn.1963822

García, J. R., \& Sala, H. (2008). The tax system incidence on unemployment: A country-specific analysis for the OECD economies. Economic Modelling, 25(6), 1232-1245. https://doi.org/10.1016/j.econmod.2008.04.003

International Labour Organisation. (1982). Resolution concerning statistics of the economically active population, employment, unemployment and underemployment. The Thirteenth International Conference of Labour $\begin{array}{llll}\text { Statisticians } & \text { (October, 1982). } & \text { Retrieved }\end{array}$ http://www.ilo.org/public/english/bureau/stat/download/res/ecacpop.pdf

Kaliontzakis, M. (2015). The curious case of greece: the impact of fiscal policy shocks on key macroeconomic variables. a var based approach. Master's Theses, University of San Francisco.

Karimi, M., \& Rodgar, A. E. (2018). To investigation the relationship between monetary, fiscal policy and economic growth in Iran (ARDL Approach to Cointegration). Islamic Azad University, Iran.

Kassab, Z. (2015). The effect of labour taxation on the employment level. Master's Thesis, Lund University, Department of Economics. Retrieved from http://lup.lub.lu.se/student-papers/record/7853468

Keynes, J. M. (2018). The general theory of employment, interest, and money. USA, Springer Publishers. https://doi.org/10.1007/978-3-319-70344-2

Kuo, C.-H., \& Miyamoto, H. (2014). Fiscal stimulus and unemployment dynamics. EMS Working Paper, Research Institute, International University of Japan.

Leigh, A., \& Neill, C. (2011). Can national infrastructure spending reduce local unemployment? Evidence from an Australian roads program. Economics Letters, 113(2), 150-153. https://doi.org/10.1016/j.econlet.2011.05.037

Lozano, I., \& Rodríguez, K. (2011). Assessing the macroeconomic effects of fiscal policy in Colombia. Journal of Financial Economic Policy, 3(3), 206-228. https://doi.org/10.1108/17576381111152209

Mahmood, H., \& Khalid, S. (2013). Fiscal policy for growth and employment generation in Pakistan. Academic Research International, 4(6), 372-381.

Matsumae, T., \& Hasumi, R. (2016). Impacts of government spending on unemployment: Evidence from a Medium-scale DSGE model. ESRI Discussion Paper Series No. 329.

Matthew, O. A., Osabohien, R., Ejemeyovwi, J. O., Ede, C. U., Akinpelumi, D. M., \& Okunbor, J. U. (2018). The interaction effect of tourism and foreign exchange earnings on economic growth in Nigeria. Global Business Review. https://doi.org/10.1177/0972150918812985

Mohseni, M., \& Jouzaryan, F. (2016). Examining the effects of inflation and unemployment on economic growth in Iran (1996-2012). Procedia Economics and Finance, 36, 381-389. https://doi.org/10.1016/S2212-5671(16)30050-8

Monacelli, T., Perotti, R., \& Trigari, A. (2010). Unemployment fiscal multipliers. Journal of Monetary Economics, 57(5), 531-553. https://doi.org/10.1016/j.jmoneco.2010.05.009 
Morozumi, A., \& Veiga, F. J. (2016). Public spending and growth: the role of government accountability. European Economic Review, 89, 148-171. https://doi.org/10.1016/j.euroecorev.2016.07.001

National Bureau of Statistics. (2017). Unemployment/under-employment report (Q4 2016). Abuja: National Bureau of Statistics.

Nwosa, P. I. (2014). Government expenditure, unemployment and poverty rates in Nigeria. Journal of Research in National Development, 12(1), 77-84.

Ogundipe, A. A., \& Oluwatobi, S. (2013). Government spending and economic growth in Nigeria: Evidence from disaggregated analysis. Journal of Business Management and Applied Economics, 2(4), 1-10.

Pesaran, M. H., Shin, Y., \& Smith, R. J. (2001). Bounds testing approaches to the analysis of level relationships. Journal of Applied Econometrics, 16(3), 289-326. https://doi.org/10.1002/jae.616

Ranasinghe, R. K., \& Ichihashi, M. (2014). The composition of government expenditure and economic growth: The case of Sri Lanka. IDEC Discussion Paper, Hiroshima University, Graduate School for International Development and Cooperation.

Rendahl, P. (2014). Fiscal policy in an unemployment crises.

Samira, M. F., \& Khalil, S. (2015). The effect of government expenditure on unemployment rate for Iran. International Journal of Review in Life Sciences, 5(7), 109-116.

Sunde, T. (2015). The effects of monetary policy on unemployment in Namibia. Journal of Economic and Social Thought, 2(4), 256-274.

Tagkalakis, A. O. (2013). The unemployment effects of fiscal policy: recent evidence from Greece. IZA Journal of European Labor Studies, 2(11). https://doi.org/10.1186/2193-9012-2-11

Ubah, J. I., Bowale, E. K., Ejemeyovwi, J. O., \& Okereke, Y. (2021). Effects of Technological Diffusion and Access to Electricity on Employment in Nigeria. International Journal of Energy Economics and Policy, 11(2), 227-233.

Ujumadu, V. (2016, September). Vanguard Nigeria. Retrieved November 26, 2017, from https://www.vanguardngr.com/2016/09/nigeria-deeply-divided-says-un-report/

Unal, U. (2015). The unemployment effects of fiscal policy in Netherlands. Journal of Faculty of Economics and Administrative Sciences, 20(1), 143-153.

World Bank. (2017). World development indicators. The World Bank.

Young, P. C., \& Pedregal, J. D. (1999). Macro-economic relativity: government spending, private ex and unemployment in the USA 1948-1998. Structural Change and Economic Dynamics, 10(3-4), 359-380. https://doi.org/10.1016/S0954-349X(99)00006-5

\section{Copyrights}

Copyright for this article is retained by the author(s), with first publication rights granted to the journal.

This is an open-access article distributed under the terms and conditions of the Creative Commons Attribution license (http://creativecommons.org/licenses/by/4.0/). 